- Jeffrey Reaser; \& Charlotte Vaughn (2008). Operationalizing linguistic gratuity: From principle to practice. Linguistic and Language Compass 3:1109-34.

Woolard, Kathryn A., \& Bambi B. Schieffelin (1994). Language ideology. Annual Review of Anthropology 23:55-82.

(Received 15 December 2017)

Address for correspondence:

Walt Wolfram

Department of English

North Carolina State University

Raleigh, North Carolina 27695-8105, USA

wolfram@ncsu.edu

\title{
Correcting whose errors? The principle of error correction from an ethnographic lens
}

\author{
V I R G I N A Z A V A L A \\ Pontificia Universidad Católica del Perú
}

Labovian sociolinguistics constitutes an important paradigm that brings to the forefront issues of social justice in linguistics and asks about the debt the scholar has towards the community once s/he gets information from it. Nevertheless, as many scholars have discussed, and even though this paradigm has focused on changing society for the better, it has serious limitations on how it conceptualizes the relationship between language and society. Based on critical race theory and language ideologies, Lewis powerfully contributes to this discussion by critiquing the principle of error correction (PEC) proposed by Labov as a particular way of conceptualizing social change. As Lewis points out at the end of the article, this principle reflects an 'earlier era' and needs to be reconsidered in light of the significant transformations not only in the study of language in society developed in recent decades but also in critical theory and humanities in general.

According to Lewis, the limits of the PEC originate in its premises about racism, social change, and representations of language. Moreover, the PEC is based on a positivist/modernist/structuralist approach to language itself. The use of terms such as 'errors', 'correction', 'misconceptions', 'objectivity', 'language myths', 'mistaken beliefs', and 'scientific fallacy', among others, reflects this. This 
terminological repertoire is also related to the widespread binary opposition 'descriptive/prescriptive' in the discipline of linguistics, which assumes that language study is objective and neutral, and lay people's 'erroneous' conceptualizations of language need 'correction' by linguists. I wonder what kind of identities and relationships are constructed between researcher and researched under this principle. Here, there are no accounts of the researcher's positionings, but only knowledge that is shared as objective 'truth'.

In the last few decades, we have been witnessing a rupture from the past through the questioning of foundational notions of classical sociolinguistics and applied linguistics, such as the boxing metaphor, the notion of the mother tongue, the perspective of language rights, the concept of diglossia, and the connection between race and language, among many others. Nevertheless, even though a critical poststructuralist sociolinguistics is gaining more and more visibility, I agree with Lewis that modernist conceptualizations of language still haunt the field. And this does not only apply to the PEC. Flores \& Rosa (2015), for example, remind us about the ideological and racializing perspectives of the listening subjects. If we assume that the listening subject can perceive objective linguistic forms isolated from ideological frames, we are displaying a positivist orientation to language, in which social reality can ostensibly be accessed in absolute and neutral terms. From a critical poststructuralist perspective, we do not study language or language forms, but rather 'language practices in interrelationship to the sociohistorical political and economic conditions that produce them' (García, Flores, \& Spotti 2017:5). Within this perspective, as Lewis points out, the marginalization of language practices is connected to the material and historical aspects of racism, and the division between language and society is impossible to make.

The discussion proposed by Lewis resonates with my experience as a Latin American and Peruvian researcher of intercultural bilingual education (IBE) with indigenous languages. As linguists, and in the name of objectivity and science, we have sometimes contributed to the marginalization of minoritized languages. In Peru, for example, linguists were involved in the creation of the Quechua phonemic alphabet in the 1980s, defending the language's 'purity' from the influence of Spanish and seeking to standardize the 'authentic' Quechua spoken by monolingual peasants from rural areas; this clashed later with many Quechua speakers' interests and initiatives. Currently, many linguists defend IBE as if it were an essential or an absolute good, promote an ideology of static traditionalism, and display a discourse of preservation of indigenous languages within an apolitical project and ecological metaphors of language diversity and endangerment (Hill 2002; Duchêne \& Heller 2008). After all, we know that all representations of language are ideological, including the ones of linguists ourselves.

Within this positioning, linguists have also tried to convince parents from rural areas of Peru that IBE constitutes a good option, as if repeating the message over and over would change their negative beliefs about these types of schools, 
especially when the beliefs are connected to material conditions that are neither addressed nor changed. How then can we assume that parents' negative beliefs about IBE are 'errors' or 'misconceptions'? Could we instead try to understand the social practices that frame those beliefs and from where they emerge? Could we revise our own perspectives about IBE and ask where they are situated and whose interests they serve? Could we analyze how this is involved with constructing an Other within colonial power relationships? This is precisely what an ethnographic and critical sociolinguistics helps us to do, because instead of attributing to the researched an error that has to be corrected, it opts for trying to understand the participants from within their own logic.

Finally, I believe that this discussion about the PEC converges in the question of how we understand and develop activism in sociolinguistics. I remember the distinction that Cameron, Frazer, Harvey, \& Rampton (1992) made between ethics, advocacy, and empowerment, as three positions researchers may take up vis-àvis their subjects, and their support towards empowering research as research 'on', 'for', and especially 'with' the subjects involved. I also recall Scollon \& Scollon's four types of ethnographic data and the observer's interactions with members as the most difficult and painful one, but also as the most rewarding and crucial one, since it allows an 'unequalled opportunity to see ourselves as others see us' (2001:20). From Latin American decolonial studies this epistemological rupture is ratified: 'the idea is no longer purity and distancing but contamination and involvement' (Castro-Gómez 2007:89). After all, the observer is always an integral piece of whatever is observed.

Ethnography also helps us to work contextually in order to avoid overarching statements about issues that we as sociolinguists have always supported and promoted, such as mother tongue education, for instance. We have to question a priori presumptions about the relationship between language and power (Rosa \& Burdick 2016), as if celebrating the valorization of stigmatized languages and varieties were a straightforward exercise in agency and empowerment, and domination and subordination correspond to distinct subject positions that any given individual experiences in absolute and continuous ways. The history of IBE in Peru and other Latin American countries has proved that this is not the case. The relationship between linguistic practices and power depends on the language ideologies that exist in particular cultural contexts and that guide the interpretation of specific and situated communicative practices.

Lewis' critique of the PEC leads us to think about how to critically address questions of access, power, and inequality when conducting research, and also to display an intellectual skepticism towards disciplinary assumptions and the meaning of concepts in the field. This would mean moving the principle of error correction to ourselves as researchers (in relation to critical reflexivity) and trying to understand - and judge - from deeply within the participants, the practices and the communities we study. 


\section{VIRGINIA ZAVALA}

\section{R E F E R E N C ES}

Cameron, Deborah; Elizabeth Frazer; Penelope Harvey; \& Ben Rampton (1992). Introduction. In Deborah Cameron, Elizabeth Frazer, Penelope Harvey, M. B. H. Rampton, \& Kay Richardson, Researching language: Issues of power and method, 1-28. London: Routledge.

Castro-Gómez, Santiago (2007). Decolonizar la universidad: La hybris del punto cero y el diálogo de saberes. In Santiago Castro-Gómez \& Ramón Grosfoguel (eds.), El giro decolonial: Reflexiones para una verdad epistémica más allá del capitalismo global, 79-91. Bogotá: Siglo del Hombre Editores.

Duchêne, Alexandre, \& Monica Heller (2008). Discourses of endangerment: Ideology and interest in the defense of languages. New York: Continuum.

Flores, Nelson, \& Jonathan Rosa (2015). Undoing appropriateness: Raciolinguistic ideologies and language diversity in education. Harvard Educational Review 85(2):149-71.

García, Ofelia; Nelson Flores; \& Massimiliano Spotti (2017). Introduction - Language and society: A critical poststructuralist perspective. In Ofelia García, Nelson Flores, \& Massimiliano Spotti (eds.), The Oxford handbook of language and society, 1-16. Oxford: Oxford University Press.

Hill, Jane H. (2002). 'Expert rhetorics' in advocacy for endangered languages: Who is listening, and what do they hear? Journal of Linguistic Anthropology 12(2):119-33.

Rosa, Jonathan, \& Christa Burdick (2016). Language ideologies. In Ofelia García, Nelson Flores, \& Massimiliano Spotti (eds.), The Oxford handbook of language and society, 103-23. Oxford: Oxford University Press.

Scollon, Ronald, \& Suzanne Wong Scollon (1995). Intercultural communication: A discourse approach. Oxford: Blackwell.

(Received 02 November 2017)

Address for correspondence:

Virginia Zavala

Departamento de Humanidades. Sección de Lingüística

Pontificia Universidad Católica del Perú

Avenida Universitaria 1801

Lima 32, Perú

vzavala@pucp.edu.pe 